\title{
The Role of Lipid Metabolism in Influenza A Virus Infection
}

\author{
Yong $\mathrm{Zhou}{ }^{1}$, Juan $\mathrm{Pu}^{1}$ and Yuping $\mathrm{Wu}^{2, *}$ \\ 1 Key Laboratory of Animal Epidemiology, Ministry of Agriculture, College of Veterinary Medicine, China \\ Agricultural University, Beijing 100193, China; zhouyong@cau.edu.cn (Y.Z.); pujuan@cau.edu.cn (J.P.) \\ 2 College of Life Science and Basic Medicine/Center for Biotechnology Research, Xinxiang University, \\ Xinxiang 453003, China \\ * Correspondence: wuyuping62@xxu.edu.cn; Tel.: +86-136-6373-9996
}

\section{check for}

updates

Citation: Zhou, Y.; Pu, J.; Wu, Y. The Role of Lipid Metabolism in Influenza A Virus Infection. Pathogens 2021, 10, 303. https://doi.org/10.3390/ pathogens 10030303

Academic Editor: Pawel Zmora

Received: 28 January 2021

Accepted: 3 March 2021

Published: 5 March 2021

Publisher's Note: MDPI stays neutral with regard to jurisdictional claims in published maps and institutional affiliations.

Copyright: (c) 2021 by the authors. Licensee MDPI, Basel, Switzerland. This article is an open access article distributed under the terms and conditions of the Creative Commons Attribution (CC BY) license (https:// creativecommons.org/licenses/by/ $4.0 /)$.

\begin{abstract}
Influenza A virus (IAV) is an important zoonotic pathogen that can cause disease in animals such as poultry and pigs, and it can cause infection and even death in humans, posing a serious threat to public health. IAV is an enveloped virus that relies on host cell metabolic systems, especially lipid metabolism systems, to complete its life cycle in host cells. On the other side, host cells regulate their metabolic processes to prevent IAV replication and maintain their normal physiological functions. This review summarizes the roles of fatty acid, cholesterol, phospholipid and glycolipid metabolism in IAV infection, proposes future research challenges, and looks forward to the prospective application of lipid metabolism modification to limit IAV infection, which will provide new directions for the development of anti-influenza drugs.
\end{abstract}

Keywords: influenza A virus (IAV); host cell; lipid metabolism; replication

\section{Introduction}

Influenza viruses are single-stranded, negative-sense RNA viruses that can be further classified into four types (A, B, C and D) based on the antigenic differences in the nucleoprotein (NP) and matrix protein (M). Among these types, influenza A virus (IAV) has the widest host range and is the most harmful. The IAV genome comprises eight segments encoding basic polymerase 2 (PB2), basic polymerase 1 (PB1), acidic polymerase (PA), hemagglutinin (HA), NP, neuraminidase (NA), M, and the nonstructural protein (NS) and can encode at least 10 essential and 7 accessory proteins [1-5]. A total of 18 different HA (H1-H18) and 11 different NA (N1-N11) subtypes of IAV have been identified in avian and bat species [6-8]. Therefore, IAVs are prone to antigenic mutations and subtype changes, leading to increased difficulty in prevention and control. Currently, H1N1 IAV and H3N2 IAV are the seasonal IAV subtypes circulating worldwide (https:/ / www.who.int/zh/news-room/fact-sheets/detail/influenza-(seasonal), access on 28 January 2021) and cause tens of thousands of deaths each year [9]. Recently, frequent incidents of human infection by various avian influenza viruses (AIVs) that have crossed the species barrier, such as $\mathrm{H} 5 \mathrm{Nx}, \mathrm{H7N}$, and H9N2, have occurred [10]. In addition, H1N1 derived from swine influenza virus (SIV) caused a global pandemic in 2009 [11], and a recently reported G4 genotype of H1N1 SIV also has the potential risk of causing a human pandemic [12]. Therefore, the study of IAV infection mechanisms and prevention and control approaches remains an extremely urgent task worldwide.

IAV does not have its own metabolic system and must depend on the host cell metabolic system to complete its life cycle. IAV manipulates the cell to initiate metabolic reprogramming in order to meet all the biomolecular needs required for its replication, while a series of host metabolic pathways are also regulated to defend against IAV infection. Thus, the virus and the host exhibit a competitive relationship in terms of metabolism. IAV as an enveloped virus; its replication process is related more strongly to the host cell's lipid metabolism than to other metabolisms. Lipids are widely distributed in living organisms, 
and not only are they an important cell structural component, but they also participate in various biological activities, such as cellular development, apoptosis, material transport and immune regulation. Cellular lipid metabolism is directly involved in almost all states of the viral life cycle (Figure 1), including the initial interaction of IAV with host cells, membrane fusion, nuclear import and export, and coordination of viral particle assembly and budding [13-16]. Moreover, lipid metabolism indirectly regulates IAV infection by affecting the immune system [17-19]. Numerous studies have shown that the characteristics of animal metabolites are greatly altered after infection with IAV [20,21] and have identified significant differences in the lipid composition of different pathogenic IAVs [22]. These results indicate that lipid metabolism not only plays a regulatory role in the process of IAV infection but also is closely related to the pathogenicity of IAV. In this review, we focus on the roles of fatty acid (FA), cholesterol (Chol), phospholipid (PL) and glycolipid (GL) metabolism in IAV infection. Understanding the relationship between lipid metabolism and IAV infection can help to further delineate the pathogenic mechanism of IAV and is highly important for the targeted development of vaccines and anti-influenza drugs.

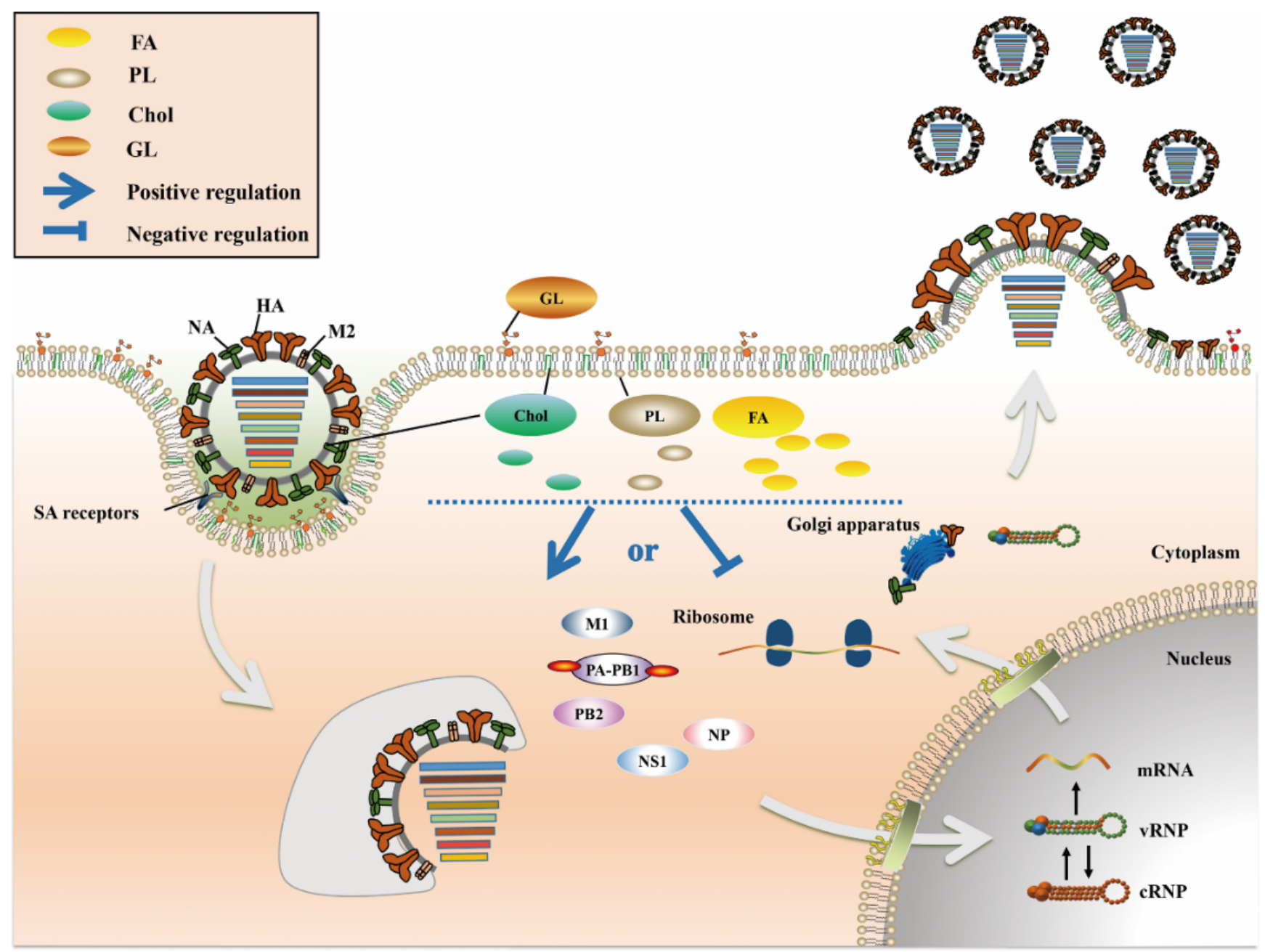

Figure 1. The role of lipid metabolism in IAV infection. FA (yellow), Chol (green), PL (dark gray) and GL (brown) are the four main lipid components present in cells, most of which are components of the biological membrane. Among these lipids, FA exist mainly in the cytoplasm, Chol and PL exist in the cell membrane and cytoplasm, and GL exist mainly in the extracellular space. After IAV infects host cells, a series of changes occur in lipid metabolism, which play a positive or negative role in multiple stages of the IAV life cycle. 


\section{Positive and Negative Regulation of FA Metabolism in IAV Infection}

FA is closely related to the inflammatory and allergic responses of organisms and widely involved in the regulation of IAV infection. Studies have shown that compared with non-obese mice, obese mice will have more severe inflammatory reaction after IAV infection due to abnormal FA metabolism [23]. By analyzing the lipid metabolites of IAV-infected mice, Morita et al. also found that polyunsaturated fatty acids (PUFA) 12-hydroxyeicosatetraenoic acid (12-HETE), 15-hydroxyeicosatetraenoic acid (15-HETE), 17-hydroxy-4,7,10,13,15,19-docosahexaenoic acid (17-HDoHE) and omega-3 PUFA-derived lipid mediator protectin D1 (PD1) inhibited IAV infection after exogenous addition and reduced the lethality of IAV infection [21]. Further studies showed that PD1 specifically inhibited the nuclear export of IAV mRNA and suppressed viral replication [24]. Another in vitro study showed that lipoxygenin B4 (LXB4), derived from omega-6 PUFA arachidonic acid (AA), promoted the expression of $B$ lymphocyte-induced maturation protein 1 (Blimp1) and X-box binding protein 1 (XBP1), the key transcription factors involved in plasma cell differentiation, thereby increasing the number of effector $B$ cells and production of IgG, which promoted host resistance to IAV [25]. In addition, through the study on the basic metabolism of lung injury and multiple organ failure caused by human H7N9 virus infection, it was found that palmitic acid, a saturated fatty acid and erucic acid, omega- 9 long chain monounsaturated fatty acid were negatively correlated with the severity of the disease, and could be used as key molecules for the prognosis of the disease [26]. In conclusion, FA such as PD1, LXB4, palmitic acid and erucic acid have negative regulatory effects on the infection process of IAV, which provides a scientific reference for the prevention and control of influenza and disease prognosis.

FA also have a positive regulatory effect on IAV infection that can exacerbate the severity of IAV infection. Studies have shown that mice fed long-chain PUFA such as eicosapentaenoic acid (EPA) and docosahexaenoic acid (DHA) have enhanced susceptibility to IAV, leading to increased morbidity and mortality [27], and further analysis revealed that EPA and DHA suppressed splenic natural killer (NK) cell activity, significantly reduced the number of CD8+ T cells in the lungs, and inhibited macrophage inflammatory protein-1 $\alpha$ (MIP- $1 \alpha)$, tumor necrosis factor- $\alpha$ (TNF- $\alpha$ ) and interleukin-6 (IL-6) mRNA expression [28], thus severely suppressing the host immune response to IAV. Not coincidentally, prostaglandin E2 (PGE2) also helps IAV evade the host immune response, inhibiting the IFN-mediated innate response and adaptive immunity. After PGE2 binds to its receptors EP2 and EP4, it can activate intracellular phosphatidylinositol 3-kinase (PI3K)-Akt and protein kinase A (PKA) signaling pathways, thereby inhibiting IRF3-mediated type I IFN activation and antigen presentation as well as $\mathrm{T}$ cell activation, exacerbating the damage caused by IAV infection [29-32]. In addition, phospholipase D (PLD), a key enzyme in FA metabolism, can promote IAV replication by inhibiting the expression of myxovirus resistance gene A (MxA) [33]. In 2010, PLD was identified as a host factor required for IAV replication [34], and PLD has potential use as an anti-influenza target drug [35].

\section{Chol Plays a Major Role in Fusion and Release during the IAV Life Cycle}

Chol is an indispensable substance in cells, not only participating in the formation of cell membranes but also serving as a precursor for the synthesis of a variety of bioactive substances. Additionally, Chol is an important component of the IAV envelope, accounting for approximately $11-12 \%$ of its total mass [36], and is very important for IAV fusion and release [37]. After binding to the sialic acid receptor, the successful entry of IAV into the cell further depends on fusion of the viral envelope with the intracellular body membrane [38], and viral envelope Chol plays a key role in this process. Pretreatment of IAV particles with different concentrations of methyl- $\beta$-cyclodextrin (soluble Chol) resulted in a dosedependent reduction in the cellular infectivity of IAV via solubilization of Chol, but this inhibition was limited to the viral fusion process $[39,40]$. In addition to the critical role in the entry stage as the viral envelope $\mathrm{Chol}$, cell membrane Chol is essential to ensure effective budding of progeny virions; the infectivity and stability of progeny virions released from 
cells deficient in cell membrane Chol are severely impaired because progeny virions acquire their envelope from the host cell membrane during budding, and Chol plays a key role in maintaining the IAV envelope structure [41-43]. In vivo, Chol homeostasis is regulated by Annexin A6 (ANXA6) [44-46]. Overexpression of ANXA6 decreased Chol levels in the cell membrane, thereby inhibiting IAV replication and propagation, and when siRNA was used to reduce the expression of ANXA6, the titer of the progeny IAV virions was increased [47]. In addition, ANXA6 inhibits IAV budding by directly interacting with influenza matrix protein 2 (M2) [48]. The CRAC motif of the M2 protein is a potential binding motif for Chol, but whether ANXA6 competes with progeny virions for binding to the CRAC motif is unknown [49]. ANXA6 may be a target for anti-influenza drugs by regulating Chol [44].

It is worth mentioning that Chol distributed on the cell membrane forms lipid rafts together with sphingolipids [50,51] Host lipid raft is selected by IAV as a host attachment factor for multivalent binding, and play a critical role in assembly and budding of progeny virions. The polyvalent binding of IAV HA protein with sialic acid receptor will cause the aggregation of lipid rafts, which leads to the concentration and aggregation of tyrosine protein kinase (RTK) and activation, and then causes the response of PI3K/Akt and other related signaling pathways, and promotes the endocytosis of IAV [52,53]. IAV also uses the "lipid raft" region on the host's cell membrane as the virus budding site. The two kinds of glycoproteins NA and HA of the virus will firstly gather in the lipid raft region, causing the membrane deformation and bending in the lipid raft region, and initiating the process of budding [54]. These indicate that the replication cycle of IAV depends on the lipid raft and is inseparable from Chol and sphingolipids.

\section{PL Metabolism Is Involved in Multiple Stages of IAV Infection}

PL includes mainly glycerophospholipids and sphingomyelin (SM), which are the main components of biological membranes. Glycerophospholipids can be further divided into many categories depending on the substitution groups, for example, phosphatidylcholine (PC), phosphatidylglycerol (PG), phosphatidylethanolamine (PE), phosphatidylserine (PS), phosphatidylinositol (PI) and cardiolipin (CL). As an enveloped virus, IAV needs to acquire an envelope from the host cell membrane during budding of progeny virions, which inevitably leads to changes in the PL content of the host cell. Alveolar type II (ATII) cells are the most important target cells of IAV; among the pulmonary surfactants synthesized by these cells, the PL content is as high as $35-50 \mathrm{mg} / \mathrm{mL}$ [55]. When infected by IAV, ATII cells undergo reprogramming of PL metabolism, and the cell surface levels of PC, PG and PE are reduced, while those of PS, PI and SM are increased [56].

Changes in glycerophospholipid levels affect IAV replication. On the one hand, glycosylation in the vicinity of cellular sialic acid receptors leads to blockade of virion binding to cellular receptors, but elevated PS levels can abolish this blockade and increase cellular susceptibility to enveloped viruses by up to 20-fold [57,58]. On the other hand, PI can exert anti-IAV effects by directly binding to IAV with high affinity, disrupting its adsorption to host cells and binding to sialic acid receptors [59]. In addition, PI can antagonize the activation of homologous ligands of Toll-like receptors (TLRs), central components of innate immunity, thereby inhibiting the transcription of proinflammatory genes, suppressing the cytokine storm induced by IAV infection and reducing damage to the organism [60,61]. This observation indicates that the reprogramming of PL metabolism is multifaceted and shows that during IAV infection, glycerophospholipids act not only as the body's "guardian" against IAV but also as an "accomplice" of IAV.

$\mathrm{SM}$ is of interest due to its important intracellular signaling and regulatory roles [61], and its three metabolites of ceramide (Cer), sphingosine (Sph), and sphingosine-1-phosphate (S1P) are biologically active signaling molecules [62]. SM and Cer play roles in promoting and inhibiting IAV infection, respectively, and some related metabolic regulatory enzymes involved in SM metabolism have been reported to have related effects (Figure 2). Increased levels of SM contribute to IAV infection, and sphingomyelin synthase (SGMS1), which catalyzes the production of SM from Cer, has a synergistic effect [63-65]. Audi et al. have 
proved that SM defects in the cell membrane and viral envelope inhibit viral infection by impairing virus adsorption and internalization [66], while in SGMS1-deficient cells infected with IAV, the transport of newly synthesized HA and NA proteins from the Golgi apparatus to the cell surface is inhibited, severely reducing the production of progeny virions [67]. In contrast, elevating the levels of Cer can inhibit IAV replication, and Cer can enhances the activation of dendritic cells (DCs), which enhances both CD8+ and CD4+ T cell responses to viral infection [68].

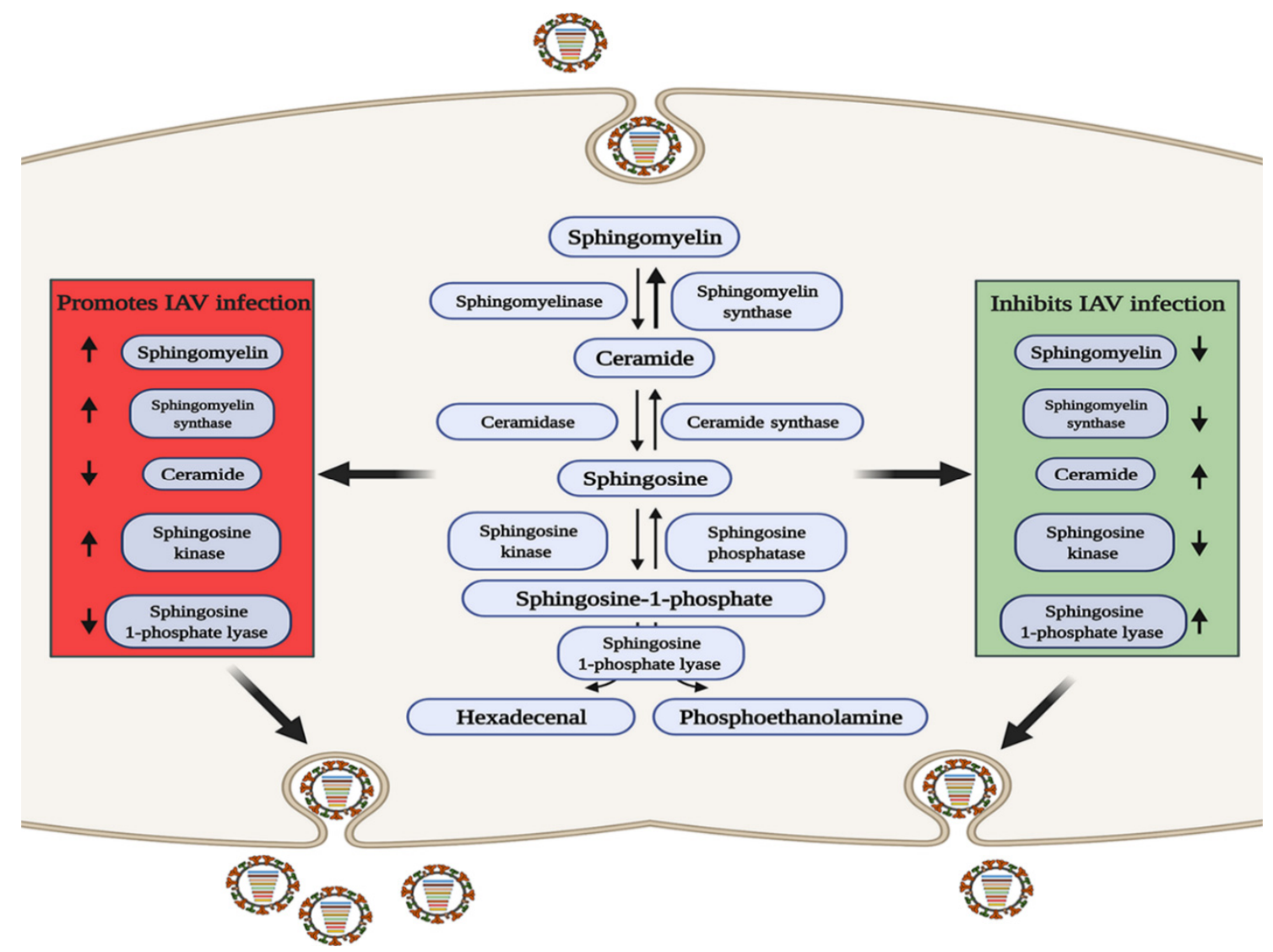

Figure 2. The role of sphingomyelin metabolism in IAV infection. In the red area, when the levels of sphingolipids or related metabolic enzymes are up-regulated or down regulated as shown by the arrow, IAV infection can be promoted through a variety of ways; conversely, in the green area, when the levels of sphingolipids or related metabolic enzymes are up-regulated or down regulated as shown by the arrow, IAV infection can be inhibited.

S1P is a terminal active metabolite of SM metabolism, and requires binding to different S1P receptor (S1PR1-S1PR5) to function. When S1PR1 is activated with CYM-5442, it can inhibit intercellular cell adhesion molecule-1 (ICAM1) production in a $\beta$-arrestin2dependent manner, thereby reducing lung injury mediated by the strong immune response triggered by IAV infection, but it cannot reduce the viral titer [69-71], indicating that S1PR1 cannot reduce viral replication but can reduce pathological damage. Sphingosine kinase 1 (SPHK1) is the key enzyme that catalyzes the generation of S1P from Sph [72,73]. In infected cells, SPHK1 was shown to promote viral RNA synthesis by activating NF- $\kappa B$ and to maintain CRM1/RanBP3-mediated nuclear export of the viral ribonucleoprotein (vRNP) complex by activating ERK and AKT [74-78]. S1P lyase (SPL), which induces S1P degradation, has also been shown to participate in the host anti-IAV response. SPL induces rapid activation of ERK and STAT1 and enhances the activation of IKK $\varepsilon$, thereby promoting the host immune response [79]. The above studies indicate that metabolites and enzymes in the SM metabolic pathway are widely involved in the regulation of IAV infection. 


\section{An Appropriate GL Concentration Is Important for IAV Infection}

GLs are a class of amphiphilic lipid compounds containing glycosyl ligands that are widespread in living organisms, and glycosphingolipids (GSLs) are a main component of the GL family with multiple cellular roles. Some previous studies concluded that IAV must bind to cell surface GSLs to successfully infect cells [80,81], but other studies demonstrated that GSL is not required for IAV infection but acts as an adsorption stabilizer only during the entry stage of the IAV life cycle [82-84]. Glucosylceramide (GlcCer) is the main component of GSLs and can be converted into glucose and Cer under the catalytic activity of glucocerebrosidase (GBA) [85], while glucosylceramide synthase (GCS) catalyzes the synthesis of GlcCer from Cer. After using CRISPR-Cas9 to knock out GBA, the level of GlcCer was increased by approximately three- to four-fold, delaying the transport of IAV to late endosomes and inhibiting IAV infection [86]. In addition, when CRISPR/Cas9 was used to knock out the GCS gene, the level of GlcCer was reduced, and the infectivity of IAV was weakened [87]. The above findings suggest that either excessive or insufficient levels of GlcCer inhibit IAV replication, suggesting that an appropriate concentration of GlcCer is extremely important for maintaining optimal IAV infection ability without dose dependency.

\section{Conclusions and Perspective}

Recently, outbreaks of zoonotic diseases worldwide have shown a rapid upward trend. IAV is a zoonotic virus; once it becomes able to effectively infect and spread in human population, it may cause serious public health incidents. Currently, prevention and control of seasonal IAV rely mainly on vaccines, but due to the variable antigenicity of IAV, vaccine candidate strains need to be reevaluated and recommended by the World Health Organization (WHO) annually, which greatly increases the socioeconomic burden. Regarding drug therapy, the current selection of drugs available for treatment of the frequently mutating IAV is limited and includes mainly M2 ion channel inhibitors and NA inhibitors. Both amantadine and rimantadine target the M2 protein and are specific for IAV [88]. Oseltamivir and zanamivir, which target the NA protein, are active against IAV and influenza B virus (IBV) [89]; however, due to frequent mutations in the IAV genome, many IAV strains are already resistant [90], and the development of new anti-influenza drugs is thus urgently needed. Lipid metabolism is involved in multiple stages of IAV replication (Figure 1, Table 1) and can constitute a direction for future research on antiinfluenza drugs. For example, the modulator of lipid raft structures composed mainly of Chol and SM is expected to become the target of new anti-influenza drugs [91-94].

The role of lipid metabolism in influenza virus infection is a new research direction, but most current research is phenotypic research. There are many research challenges we are facing, including two major issues. We want to know (a) which mechanism triggers changes in lipid metabolism during influenza infection and (b) how host lipid metabolism defends viral infection and recovers its normal level. More specifically, lipid metabolism is known to have an important balance including deficiency or overaccumulation of lipids; however, the current studies mainly focus on the effect of single specific lipid metabolite in IAV infection, and it is necessary to further understand the role of the balance between different lipid metabolites in viral infection. Moreover, changes in lipid metabolites level may not only inhibit or promote IAV infections but also cause metabolic disorders in the body. Therefore, it is necessary to systematically evaluate the pathogenic effect of IAV infection due to metabolic disorders and how the body responds and restores lipid metabolite balance to reduce the pathogenic effect. In addition, the specific mechanism by which many lipid metabolites exert their effects during IAV infection is currently unclear, and changes in lipid metabolites level rely mainly on the regulation of related metabolic enzymes; thus, the role of lipid metabolites in IAV infection, whether dominated by an enzyme itself or the lipid metabolites regulated by the enzyme, needs further clarification. Although many problems remain to be explored and solved, with the development and improvement of lipidomic techniques, the combined use of multiomics, and innovations in 
science and technology, the study of the mechanism by which lipid metabolism impacts IAV infection has become simpler and faster, allowing possible screening of lipid targets of anti-influenza drugs in the future.

Table 1. The roles of lipid metabolism in IAV infection.

\begin{tabular}{|c|c|c|c|}
\hline Type of Metabolism & Name of Component & Role in IAV Infection & Reference \\
\hline \multirow{6}{*}{ FA } & $\begin{array}{l}\text { 12-HETE, 15-HETE, } \\
\text { 17-HDoHE }\end{array}$ & Inhibits IAV infection in vitro & [21] \\
\hline & PD1 & Inhibits nuclear export of IAV mRNA & {$[21,24]$} \\
\hline & LXB4 & Promotes the production of effector B cells and IgG & [25] \\
\hline & EPA, DHA & Inhibits innate and adaptive immunity & {$[28]$} \\
\hline & PGE2 & $\begin{array}{l}\text { Inhibits IFN-mediated innate immunity and } \\
\text { impairs adaptive immunity }\end{array}$ & [32] \\
\hline & PLD & Promotes host innate immune evasion by IAV & [33] \\
\hline \multirow{2}{*}{ Chol } & Viral envelope Chol & \multirow{2}{*}{$\begin{array}{c}\text { Promotes the fusion of IAV particles } \\
\text { Improves the infectivity and stability of progeny } \\
\text { virions }\end{array}$} & [39] \\
\hline & Cell membrane Chol & & [41] \\
\hline \multirow{7}{*}{ PL } & PS & Promotes the susceptibility of cells to IAV infection & [57] \\
\hline & PI & $\begin{array}{l}\text { Binds to IAV with high affinity and inhibits } \\
\text { inflammation induced by IAV infection }\end{array}$ & {$[60]$} \\
\hline & $\mathrm{SM}$ & $\begin{array}{c}\text { Promotes the fusion and infectivity of progeny } \\
\text { virions }\end{array}$ & {$[61,66]$} \\
\hline & Cer & $\begin{array}{c}\text { Promotes the adaptive immune response after viral } \\
\text { infection }\end{array}$ & [63] \\
\hline & SGMS1 & Promotes the release of progeny virions & [67] \\
\hline & SPHK1 & Promotes vRNA synthesis and vRNP nuclear export & {$[74,77,78]$} \\
\hline & SPL & Enhances the immune response to IAV & [79] \\
\hline GL & GlcCer & Maintains the optimal state of IAV infection & [86] \\
\hline
\end{tabular}

Funding: This work was supported by Key Scientific Research Projects of Higher Education in Henan Province (19B230015), Doctoral Research Initiation Fund of Xinxiang University (1366020122) and The National Science Fund for Distinguished Young Scholars (31922082).

Institutional Review Board Statement: Not applicable.

Informed Consent Statement: Not applicable.

Data Availability Statement: Data is contained within the article.

Conflicts of Interest: The authors declare that they have no conflict of interest.

\section{References}

1. Wise, H.M.; Foeglein, A.; Sun, J.; Dalton, R.M.; Patel, S.; Howard, W.; Anderson, E.C.; Barclay, W.S.; Digard, P. A Complicated Message: Identification of a Novel PB1-Related Protein Translated from Influenza A Virus Segment 2 mRNA. J. Virol. 2009, 83, 8021-8031. [CrossRef] [PubMed]

2. Chen, W.S.; Calvo, P.A.; Malide, D.; Gibbs, J.; Schubert, U.; Bacik, I.; Basta, S.; O’Neill, R.; Schickli, J.; Palese, P.; et al. A novel influenza a virus mitochondrial protein that induces cell death. Nat. Med. 2001, 7, 1306-1312. [CrossRef]

3. Jagger, B.W.; Wise, H.M.; Kash, J.C.; Walters, K.; Wills, N.M.; Xiao, Y.; Dunfee, R.L.; Schwartzman, L.M.; Ozinsky, A.; Bell, G.L.; et al. An Overlapping Protein-Coding Region in Influenza A Virus Segment 3 Modulates the Host Response. Science 2012, 337, 199-204. [CrossRef]

4. Wise, H.M.; Hutchinson, E.C.; Jagger, B.W.; Stuart, A.D.; Kang, Z.H.; Robb, N.; Schwartzman, L.M.; Kash, J.C.; Fodor, E.; Firth, A.E.; et al. Identification of a Novel Splice Variant Form of the Influenza A Virus M2 Ion Channel with an Antigenically Distinct Ectodomain. PLoS Pathog. 2012, 8, e1002998. [CrossRef]

5. Muramoto, Y.; Noda, T.; Kawakami, E.; Akkina, R.; Kawaoka, Y. Identification of Novel Influenza a Virus Proteins Translated from PA mRNA. J. Virol. 2013, 87, 2455-2462. [CrossRef] [PubMed]

6. Tong, S.; Li, Y.; Rivailler, P.; Conrardy, C.; Alvarez Castillo, D.A.; Chen, L.; Recuenco, S.; Ellison, J.A.; Davis, C.T.; York, I.A.; et al. A distinct lineage of influenza a virus from bats. Proc. Natl. Acad. Sci. USA 2012, 109, 4269-4274. [CrossRef] [PubMed] 
7. Fouchier, R.; Munster, V.; Wallensten, A.; Bestebroer, T.M.; Herfst, S.; Smith, D.; Rimmelzwaan, G.F.; Olsen, B.; Osterhaus, A. Characterization of a novel influenza a virus hemagglutinin subtype (H16) obtained from black-headed gulls. J. Virol. 2005, 79, 2814-2822. [CrossRef]

8. Tong, S.; Zhu, X.; Li, Y.; Shi, M.; Zhang, J.; Bourgeois, M.; Yang, H.; Chen, X.; Recuenco, S.; Gomez, J.; et al. New World Bats Harbor Diverse Influenza A Viruses. PLoS Pathog. 2013, 9, e1003657. [CrossRef]

9. Iuliano, A.D.; Roguski, K.M.; Chang, H.H.; Muscatello, D.J.; Palekar, R.; Tempia, S.; Cohen, C.; Gran, J.M.; Schanzer, D.; Cowling, B.J.; et al. Estimates of global seasonal influenza-associated respiratory mortality: A modelling study. Lancet 2018, 391, 1285-1300. [CrossRef]

10. Gao, R.; Cao, B.; Hu, Y.; Feng, Z.; Wang, D.; Hu, W.; Chen, J.; Jie, Z.; Qiu, H.; Xu, K.; et al. Human Infection with a Novel Avian-Origin Influenza A (H7N9) Virus. N. Engl. J. Med. 2013, 368, 1888-1897. [CrossRef]

11. Vijaykrishna, D.; Poon, L.L.M.; Zhu, H.C.; Ma, S.K.; Li, O.T.W.; Cheung, C.L.; Smith, G.J.D.; Peiris, J.S.M.; Guan, Y. Reassortment of Pandemic H1N1/2009 Influenza A Virus in Swine. Science 2010, 328, 1529. [CrossRef]

12. Sun, H.; Xiao, Y.; Liu, J.; Wang, D.; Li, F.; Wang, C.; Li, C.; Zhu, J.; Song, J.; Sun, H.; et al. Prevalent Eurasian avian-like H1N1 swine influenza virus with 2009 pandemic viral genes facilitating human infection. Proc. Natl. Acad. Sci. USA 2020, 117, 17204-17210. [CrossRef]

13. Heaton, N.S.; Randall, G. Multifaceted roles for lipids in viral infection. Trends Microbiol. 2011, 19, 368-375. [CrossRef] [PubMed]

14. Sun, X.J.; Whittaker, G.R. Role for influenza virus envelope cholesterol in virus entry and infection. J. Virol. 2003, 77, 12543-12551. [CrossRef]

15. Chazal, N.; Gerlier, D. Virus entry, assembly, budding, and membrane rafts. Microbiol. Mol. Biol. Rev. 2003, 67, 226-237. [CrossRef] [PubMed]

16. Nayak, D.P.; Balogun, R.A.; Yamada, H.; Zhou, Z.H.; Barman, S. Influenza virus morphogenesis and budding. Virus Res. 2009, 143, 147-161. [CrossRef] [PubMed]

17. Ko, E.; Lee, Y.; Lee, Y.; Kim, K.; Kang, S. Distinct Effects of Monophosphoryl Lipid A, Oligodeoxynucleotide CpG, and Combination Adjuvants on Modulating Innate and Adaptive Immune Responses to Influenza Vaccination. Immune Net. 2017, 17, 326-342. [CrossRef]

18. Oguin, T.; Lindsley, C.; Thomas, P.; Brown, H. Effects of lipid signaling on innate immune networks during influenza infection. J. Immunol. 2015, 194 (Suppl. 1), 127.1.

19. Schoggins, J.W.; Randall, G. Lipids in Innate Antiviral Defense. Cell Host Microbe 2013, 14, 379-385. [CrossRef]

20. Cui, L.; Zheng, D.; Lee, Y.H.; Chan, T.K.; Kumar, Y.; Ho, W.E.; Chen, J.Z.; Tannenbaum, S.R.; Ong, C.N. Metabolomics Investigation Reveals Metabolite Mediators Associated with Acute Lung Injury and Repair in a Murine Model of Influenza Pneumonia. Sci. Rep. 2016, 6, 26076. [CrossRef]

21. Schultz, D.; Methling, K.; Rothe, M.; Lalk, M. Eicosanoid Profile of Influenza A Virus Infected Pigs. Metabolites 2019, 9, 130. [CrossRef]

22. Ivanova, P.T.; Myers, D.S.; Milne, S.B.; McClaren, J.L.; Thomas, P.G.; Brown, H.A. Lipid Composition of the Viral Envelope of Three Strains of Influenza Virus-Not All Viruses Are Created Equal. ACS Infect. Dis. 2015, 1, 435-442. [CrossRef] [PubMed]

23. Milner, J.J.; Rebeles, J.; Dhungana, S.; Stewart, D.A.; Sumner, S.C.J.; Meyers, M.H.; Mancuso, P.; Beck, M.A. Obesity Increases Mortality and Modulates the Lung Metabolome during Pandemic H1N1 Influenza Virus Infection in Mice. J. Immunol. 2015, 194, 4846-4859. [CrossRef]

24. Morita, M.; Kuba, K.; Ichikawa, A.; Nakayama, M.; Katahira, J.; Iwamoto, R.; Watanebe, T.; Sakabe, S.; Daidoji, T.; Nakamura, S.; et al. The Lipid Mediator Protectin D1 Inhibits Influenza Virus Replication and Improves Severe Influenza. Cell 2013, 153, 112-125. [CrossRef] [PubMed]

25. Kim, N.; Lannan, K.L.; Thatcher, T.H.; Pollock, S.J.; Woeller, C.F.; Phipps, R.P. Lipoxin B-4 Enhances Human Memory B Cell Antibody Production via Upregulating Cyclooxygenase-2 Expression. J. Immunol. 2018, 201, 3343-3351. [CrossRef] [PubMed]

26. Sun, X.; Song, L.; Feng, S.; Li, L.; Yu, H.; Wang, Q.; Wang, X.; Hou, Z.; Li, X.; Li, Y.; et al. Fatty Acid Metabolism is Associated with Disease Severity After H7N9 Infection. EBioMedicine 2018, 33, 218-229. [CrossRef] [PubMed]

27. Byleveld, P.M.; Pang, G.T.; Clancy, R.L.; Roberts, D. Fish oil feeding delays influenza virus clearance and impairs production of interferon-gamma and virus-specific immunoglobulin A in the lungs of mice. J. Nutr. 1999, 129, 328-335. [CrossRef]

28. Schwerbrock, N.M.J.; Karlsson, E.A.; Shi, Q.; Sheridan, P.A.; Beck, M.A. Fish oil-fed mice have impaired resistance to influenza infection. J. Nutr. 2009, 139, 1588-1594. [CrossRef]

29. Hussell, T.; Bell, T.J. Alveolar macrophages: Plasticity in a tissue-specific context. Nat. Rev. Immunol. 2014, 14, 81-93. [CrossRef]

30. Smith, W.L. The eicosanoids and their biochemical-mechanisms of action. Biochem. J. 1989, 259, 315-324. [CrossRef]

31. Full, F.; Gack, M.U. Prostaglandin E-2: The Villain in the Host Response to Influenza Virus. Immunity 2014, 40, 453-454. [CrossRef]

32. Coulombe, F.; Jaworska, J.; Verway, M.; Tzelepis, F.; Massoud, A.; Gillard, J.; Wong, G.; Kobinger, G.; Xing, Z.; Couture, C.; et al. Targeted Prostaglandin E-2 Inhibition Enhances Antiviral Immunity through Induction of Type I Interferon and Apoptosis in Macrophages. Immunity 2014, 40, 554-568. [CrossRef]

33. Oguin, T.H.I.; Sharma, S.; Stuart, A.D.; Duan, S.; Scott, S.A.; Jones, C.K.; Daniels, J.S.; Lindsley, C.W.; Thomas, P.G.; Brown, H.A. Phospholipase D Facilitates Efficient Entry of Influenza Virus, Allowing Escape from Innate Immune Inhibition. J. Biol. Chem. 2014, 289, 25405-25417. [CrossRef] 
34. Karlas, A.; Machuy, N.; Shin, Y.; Pleissner, K.; Artarini, A.; Heuer, D.; Becker, D.; Khalil, H.; Ogilvie, L.A.; Hess, S.; et al. Genome-wide RNAi screen identifies human host factors crucial for influenza virus replication. Nature 2010, 463, 132-818. [CrossRef]

35. Behera, D.K.; Behera, P.M.; Acharya, L.; Dixit, A. Pharmacophore modelling, virtual screening and molecular docking studies on PLD1 inhibitors. SAR QSAR Environ. Res. 2017, 28, 991-1009. [CrossRef] [PubMed]

36. Lenard, J.; Compans, R.W. Mmbrabe structure of lipid-containing viruses. Biochim. Biophys. Acta 1974, 344, 51-94. [CrossRef]

37. Domanska, M.K.; Wrona, D.; Kasson, P.M. Multiphasic Effects of Cholesterol on Influenza Fusion Kinetics Reflect Multiple Mechanistic Roles. Biophys. J. 2013, 105, 1383-1387. [CrossRef] [PubMed]

38. Colman, P.M.; Lawrence, M.C. The structural biology of type I viral membrane fusion. Nat. Rev. Mol. Cell Biol. 2003, 4, 309-319. [CrossRef] [PubMed]

39. Dunning, R.A.; Domanska, M.K.; Dryden, K.; Yeager, M.; Kasson, P.M. Effect of Cholesterol Depletion on HA Distribution in the Viral Membrane of Influenza. Biophys. J. 2015, 1081, 406A-407A. [CrossRef]

40. Liu, K.N.; Boxer, S.G. Target Membrane Cholesterol Modulates Single Influenza Virus Membrane Fusion Efficiency but Not Rate. Biophys. J. 2020, 118, 2426-2433. [CrossRef]

41. Bajimaya, S.; Frankl, T.; Hayashi, T.; Takimoto, T. Cholesterol is required for stability and infectivity of influenza A and respiratory syncytial viruses. Virology 2017, 510, 234-241. [CrossRef] [PubMed]

42. Goronzy, I.N.; Rawle, R.J.; Boxer, S.G.; Kasson, P.M. Cholesterol enhances influenza binding avidity by controlling nanoscale receptor clustering. Chem. Sci. 2018, 9, 2340-2347. [CrossRef] [PubMed]

43. Sieczkarski, S.B.; Whittaker, G.R. Influenza virus can enter and infect cells in the absence of clathrin-mediated endocytosis. J. Virol. 2002, 76, 10455-10464. [CrossRef]

44. Cubells, L.; de Muga, S.V.; Tebar, F.; Wood, P.; Evans, R.; Ingelmo-Torres, M.; Calvo, M.; Gaus, K.; Pol, A.; Grewal, T.; et al. Annexin A6-induced alterations in cholesterol transport and caveolin export from the golgi complex. Traffic 2007, 8, 1568-1589. [CrossRef] [PubMed]

45. Gerke, V.; Creutz, C.E.; Moss, S.E. Annexins: Linking Ca2+ signalling to membrane dynamics. Nat. Rev. Mol. Cell Biol. 2005, 6, 449-461. [CrossRef] [PubMed]

46. De Diego, I.; Schwartz, F.; Siegfried, H.; Dauterstedt, P.; Heeren, J.; Beisiegel, U.; Enrich, C.; Grewal, T. Cholesterol modulates the membrane binding and intracellular distribution of annexin 6. J. Biol. Chem. 2002, 277, 32187-32194. [CrossRef]

47. Musiol, A.; Gran, S.; Ehrhardt, C.; Ludwig, S.; Grewal, T.; Gerke, V.; Rescher, U. Annexin A6-balanced late endosomal cholesterol controls influenza A replication and propagation. MBio 2013, 4, e00608-13. [CrossRef]

48. Ma, H.; Kien, F.; Maniere, M.; Zhang, Y.; Lagarde, N.; Tse, K.S.; Poon, L.L.M.; Nal, B. Human Annexin A6 Interacts with Influenza A Virus Protein M2 and Negatively Modulates Infection. J. Virol. 2012, 86, 1789-1801. [CrossRef]

49. Schroeder, C. Cholesterol-binding viral proteins in virus entry and morphogenesis. Subcell Biochem. 2010, 51, 77-108.

50. Brown, D.A.; London, E. Structure and function of sphingolipid- and cholesterol-rich membrane rafts. J. Biol. Chem. 2000, 275, 17221-17224. [CrossRef] [PubMed]

51. Simons, K.; Ikonen, E. Functional rafts in cell membranes. Nature 1997, 387, 569-572. [CrossRef] [PubMed]

52. Eierhoff, T.; Hrincius, E.R.; Rescher, U.; Ludwig, S.; Ehrhardt, C. The Epidermal Growth Factor Receptor (EGFR) Promotes Uptake of Influenza A Viruses (IAV) into Host Cells. PLoS Pathog. 2010, 6, e1001099. [CrossRef]

53. Verma, D.K.; Gupta, D.; Lal, S.K. Host Lipid Rafts Play a Major Role in Binding and Endocytosis of Influenza A Virus. Viruses 2018, 10, 650. [CrossRef]

54. Zhang, J.; Pekosz, A.; Lamb, R.A. Influenza virus assembly and lipid raft microdomains: A role for the cytoplasmic tails of the spike glycoproteins. J. Virol. 2000, 74, 4634-4644. [CrossRef]

55. Lewis, J.F.; Jobe, A.H. Surfactant and the adult respiratory-distress syndrome. Am. Rev. Respir. Dis. 1993, 147, 218-233. [CrossRef]

56. Woods, P.S.; Doolittle, L.M.; Rosas, L.E.; Joseph, L.M.; Calomeni, E.P.; Davis, I.C. Lethal H1N1 influenza A virus infection alters the murine alveolar type II cell surfactant lipidome. Am. J. Physiol.-Lung C 2016, 311, L1160-L1169. [CrossRef] [PubMed]

57. Coil, D.A.; Miller, A.D. Phosphatidylserine treatment relieves the block to retrovirus infection of cells expressing glycosylated virus receptors. Retrovirology 2005, 2, 49. [CrossRef] [PubMed]

58. Voelker, D.R.; Numata, M. Phospholipid regulation of innate immunity and respiratory viral infection. J. Biol. Chem. 2019, 294, 4282-4289. [CrossRef] [PubMed]

59. Numata, M.; Mitchell, J.R.; Tipper, J.L.; Brand, J.D.; Trombley, J.E.; Nagashima, Y.; Kandasamy, P.; Chu, H.W.; Harrod, K.S.; Voelker, D.R. Pulmonary surfactant lipids inhibit infections with the pandemic H1N1 influenza virus in several animal models. J. Biol. Chem. 2020, 295, 1704-1715. [CrossRef] [PubMed]

60. Numata, M.; Kandasamy, P.; Nagashima, Y.; Posey, J.; Hartshorn, K.; Woodland, D.; Voelker, D.R. Phosphatidylglycerol Suppresses Influenza A Virus Infection. Am. J. Respir. Cell Mol. Boil. 2012, 46, 479-487. [CrossRef]

61. Hannun, Y.A.; Obeid, L.M. Sphingolipids and their metabolism in physiology and disease. Nat. Rev. Mol. Cell Biol. 2018, 19, 175-191. [CrossRef]

62. Maceyka, M.; Payne, S.G.; Milstien, S.; Spiegel, S. Sphingosine kinase, sphingosine-1-phosphate, and apoptosis. Biochim. Biophys. Acta 2002, 1585, 193-201. [CrossRef]

63. Soudani, N.; Hage-Sleiman, R.; Karam, W.; Dbaibo, G.; Zaraket, H. Ceramide Suppresses Influenza A Virus Replication In Vitro. J. Virol. 2019, 93, e00053-19. [CrossRef] 
64. Santinha, D.R.; Marques, D.R.; Maciel, E.A.; Simoes, C.S.O.; Rosa, S.; Neves, B.M.; Macedo, B.; Domingues, P.; Cruz, M.T.; Domingues, M.R.M. Profiling changes triggered during maturation of dendritic cells: A lipidomic approach. Anal. Bioanal. Chem. 2012, 403, 457-471. [CrossRef]

65. Chiba, N.; Masuda, A.; Yoshikai, Y.; Matsuguchi, T. Ceramide inhibits LPS-Induced production of IL-5, IL-10, and IL-13 from mast cells. J. Cell. Physiol. 2007, 213, 126-136. [CrossRef]

66. Audi, A.; Soudani, N.; Dbaibo, G.; Zaraket, H. Depletion of Host and Viral Sphingomyelin Impairs Influenza Virus Infection. Front. Microbiol. 2020, 11, 612. [CrossRef]

67. Tafesse, F.G.; Sanyal, S.; Ashour, J.; Guimaraes, C.P.; Hermansson, M.; Somerharju, P.; Ploegh, H.L. Intact sphingomyelin biosynthetic pathway is essential for intracellular transport of influenza virus glycoproteins. Proc. Natl. Acad. Sci. USA 2013, 110, 6406-6411. [CrossRef] [PubMed]

68. Pritzl, C.J.; Seo, Y.; Xia, C.; Vijayan, M.; Stokes, Z.D.; Hahm, B. A Ceramide Analogue Stimulates Dendritic Cells to Promote T Cell Responses upon Virus Infections. J. Immunol. 2015, 194, 4339-4349. [CrossRef] [PubMed]

69. Zhao, J.; Zhu, M.; Jiang, H.; Shen, S.; Su, X.; Shi, Y. Combination of sphingosine-1-phosphate receptor 1 (S1PR1) agonist and antiviral drug: A potential therapy against pathogenic influenza virus. Sci. Rep. 2019, 9, 5272. [CrossRef]

70. Oldstone, M.B.; Rosen, H. Cytokine storm plays a direct role in the morbidity and mortality from influenza virus infection and is chemically treatable with a single sphingosine-1-phosphate agonist molecule. Curr. Top. Microbiol. Immunol. 2014, 378, 129-147. [PubMed]

71. Jiang, H.; Shen, S.M.; Yin, J.; Zhang, P.P.; Shi, Y. Sphingosine 1-phosphate receptor 1 (S1PR1) agonist CYM5442 inhibits expression of intracellular adhesion molecule 1 (ICAM1) in endothelial cells infected with influenza A viruses. PLoS ONE 2017, 12, e175188. [CrossRef]

72. Gandy, K.A.O.; Obeid, L.M. Regulation of the sphingosine kinase/sphingosine 1-phosphate pathway. Handb. Exp. Pharmacol. 2013, 216, 275-303.

73. Pitson, S.M. Regulation of sphingosine kinase and sphingolipid signaling. Trends Biochem. Sci. 2011, 36, 97-107. [CrossRef] [PubMed]

74. Xia, C.; Seo, Y.; Studstill, C.J.; Vijayan, M.; Wolf, J.J.; Hahm, B. Transient inhibition of sphingosine kinases confers protection to influenza A virus infected mice. Antivir. Res. 2018, 158, 171-177. [CrossRef]

75. Hait, N.C.; Oskeritzian, C.A.; Paugh, S.W.; Milstien, S.; Spiegel, S. Sphingosine kinases, sphingosine 1-phosphate, apoptosis and diseases. Biochim. Biophys. Acta 2006, 1758, 2016-2026. [CrossRef] [PubMed]

76. Seo, Y.; Pritzl, C.J.; Vijayan, M.; Bomb, K.; McClain, M.E.; Alexander, S.; Hahm, B. Sphingosine Kinase 1 Serves as a Pro-Viral Factor by Regulating Viral RNA Synthesis and Nuclear Export of Viral Ribonucleoprotein Complex upon Influenza Virus Infection. PLoS ONE 2013, 8, e75005. [CrossRef]

77. Carr, J.M.; Mahalingam, S.; Bonder, C.S.; Pitson, S.M. Sphingosine kinase 1 in viral infections. Rev. Med. Virol. 2013, 23, 73-84. [CrossRef]

78. Kumar, N.; Xin, Z.; Liang, Y.; Ly, H.; Liang, Y. NF-kappa B Signaling Differentially Regulates Influenza Virus RNA Synthesis. J. Virol. 2008, 82, 9880-9889. [CrossRef] [PubMed]

79. Seo, Y.; Blake, C.; Alexander, S.; Hahm, B. Sphingosine 1-Phosphate-Metabolizing Enzymes Control Influenza Virus Propagation and Viral Cytopathogenicity. J. Virol. 2010, 84, 8124-8131. [CrossRef]

80. Gambaryan, A.S.; Tuzikov, A.B.; Pazynina, G.V.; Webster, R.G.; Matrosovich, M.N.; Bovin, N.V. H5N1 chicken influenza viruses display a high binding affinity for Neu5Ac alpha 2-3Gal beta 1-4(6-HSO3) GlcNAc-containing receptors. Virology 2004, 326, 310-316. [CrossRef]

81. Hidari, K.I.P.J.; Shimada, S.; Suzuki, Y.; Suzuki, T. Binding kinetics of influenza viruses to sialic acid-containing carbohydrates. Glycoconj. J. 2007, 24, 583-590. [CrossRef]

82. Ablan, S.; Rawat, S.S.; Blumenthal, R.; Puri, A. Entry of influenza virus into a glycosphingolipid-deficient mouse skin fibroblast cell line. Arch. Virol. 2001, 146, 2227-2238. [CrossRef]

83. Chu, V.C.; Whittaker, G.R. Influenza virus entry and infection require host cell N-linked glycoprotein. Proc. Natl. Acad. Sci. USA 2004, 101, 18153-18158. [CrossRef]

84. Kasson, P.M.; Pande, V.S. Structural basis for influence of viral glycans on ligand binding by influenza hemagglutinin. Biophys. J. 2008, 95, L48-L50. [CrossRef] [PubMed]

85. Ishibashi, Y.; Kohyama-Koganeya, A.; Hirabayashi, Y. New insights on glucosylated lipids: Metabolism and functions. Biochim. Biophys. Acta 2013, 1831, 1475-1485. [CrossRef] [PubMed]

86. Drews, K.; Calgi, M.P.; Harrison, W.C.; Drews, C.M.; Costa-Pinheiro, P.; Shaw, J.J.P.; Jobe, K.A.; Nelson, E.A.; Han, J.D.; Fox, T.; et al. Glucosylceramidase Maintains Influenza Virus Infection by Regulating Endocytosis. J. Virol. 2019, 93, e00017-19. [CrossRef] [PubMed]

87. Drews, K.; Calgi, M.P.; Harrison, W.C.; Drews, C.M.; Costa-Pinheiro, P.; Shaw, J.J.P.; Jobe, K.A.; Han, J.D.; Fox, T.E.; White, J.M.; et al. Glucosylceramide synthase maintains influenza virus entry and infection. PLoS ONE 2020, 15, e0228735. [CrossRef] [PubMed]

88. Pinto, L.H.; Lamb, R.A. Understanding the mechanism of action of the antiinfluenza virus drug amantadine. Trends Microbiol. 1995, 3, 271. [CrossRef]

89. Gubareva, L.V.; Kaiser, L.; Hayden, F.G. Influenza virus neuraminidase inhibitors. Lancet 2000, 355, 827-835. [CrossRef] 
90. Shankaran, S.; Bearman, G.M.L. Influenza Virus Resistance to Neuraminidase Inhibitors: Implications for Treatment. Curr. Infect. Dis. Rep. 2012, 14, 155-160. [CrossRef]

91. Simons, K.; Toomre, D. Lipid rafts and signal transduction. Nat. Rev. Mol. Cell Biol. 2000, 1, 31-39. [CrossRef]

92. Brown, D.A.; London, E. Functions of lipid rafts in biological membranes. Annu. Rev. Cell Dev. Biol. 1998, 14, 111-136. [CrossRef] [PubMed]

93. Barman, S.; Nayak, D.P. Lipid raft disruption by cholesterol depletion enhances influenza a virus budding from MDCK cells. J. Virol. 2007, 81, 12169-12178. [CrossRef] [PubMed]

94. Agarwal, S.; Schroeder, C.; Schlechtingen, G.; Braxmeier, T.; Jennings, G.; Knoelker, H. Evaluation of steroidal amines as lipid raft modulators and potential anti-influenza agents. Bioorg. Med. Chem. Lett. 2013, 23, 5165-5169. [CrossRef] [PubMed] 